CZASOPISMO INŻYNIERII LADDOWEJ, ŚRODOWISKA I ARCHITEKTURY JOURNAL OF CIVIL ENGINEERING, ENVIRONMENT AND ARCHITECTURE JCEEA, t. XXXII, z. 62 (3/II/15), lipiec-wrzesień 2015, s. 135-148

\author{
Grzegorz GREMZA ${ }^{1}$
}

Jan ZAMOROWSKI ${ }^{2}$

\title{
SELECTED ASPECTS OF CALCULATING CRANE SUPPORTING BEAMS
}

\begin{abstract}
During the last few years the European Standards (EN) for designing the overhead crane beams has been introduced by many countries. The general design approach and detailed guidelines presented in these documents are partly different from the previous obligatory national design rules. The calculation based on new rules mostly reveals greater use of the terms of the load capacity, especially it concerns the fatigue load capacity. Such a results lead to designing of the oversized crosssection. On the other hand the investors' requirements to extremely reduce the weight of the construction is a big challenge to the structural engineers and that enforced them to design the constructions without any reserve of the load capacity. In such a context the legitimacy of the simplified calculation method that has been used so far is discussed in this paper. For this purpose the exemplary calculations of beams with varied cross-sections by use of the precise and simplified method were executed. The conclusions concerning differences in stresses values resulting from acceptance of simplified model have been shown. The issues connected with the assessment of the fatigue load capacity are mentioned also in this paper especially focusing on the load capacity of the elements with holes. The American and European standards and another guidelines have been analysed in the aforementioned context and compared with accessible test results.
\end{abstract}

Keywords: fatigue life, construction details with holes, simplified method, stress

\section{Calculating the normal stresses}

\subsection{Traditional simplified and precise method}

So far according to the Polish Standard [1] and outlines using in other countries, eg. [11], the simplified model was used to check the load capacity of the beams with a brace. Such an approach was based on the independent stress checking in the main runway beam and in the horizontal brace. The horizontal brace

\footnotetext{
${ }^{1}$ Author for correspondence: Grzegorz Gremza, Silesian University of Technology, 44-100 Gliwice, ul. Akademicka 5, 662349538, ggre@interia.pl.

2 Jan Zamorowski, University of Bielsko-Biała, ATH, 43-309 Bielsko-Biała, ul. Willowa 2, zamski@interia.pl.
} 
was constructed from the outer belt and the inner belt that consisted of the upper flange of the main beam and part of its web, joined together with the horizontal plate or lacings. Obtained stresses that come from the bending of the two mentally separated elements were summarized in the outer fibers of the upper beam flange (Fig. 1).

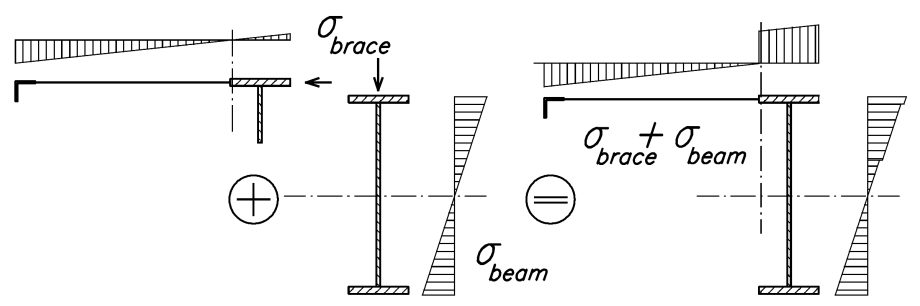

Fig. 1. Traditional scheme of stress calculation in beams with brace

Rys. 1. Tradycyjny schemat obliczania naprężeń w belkach ze stężeniem

The influence of the torsion which is the result of the eccentricity of loading forces relative to the shear centre was ignored in this approach. In case of beams with a big horizontal braces the shear center is placed close to the crossing of the web axis and the axis of the upper flange of the beam, thus torsion being the results of the action of the same forces is significantly weaker than the torsion in the beam without a brace. Simultaneously the cross-section of the beams with braces are mostly higher than the beams without braces. Therefore the additional stresses resulting from bi-moment horizontal bending of the belts can be lower that in other beams. At present in the [5] there are requirements to include the torque resulting from the eccentricities in calculations apart from the type of the beam that is designed.

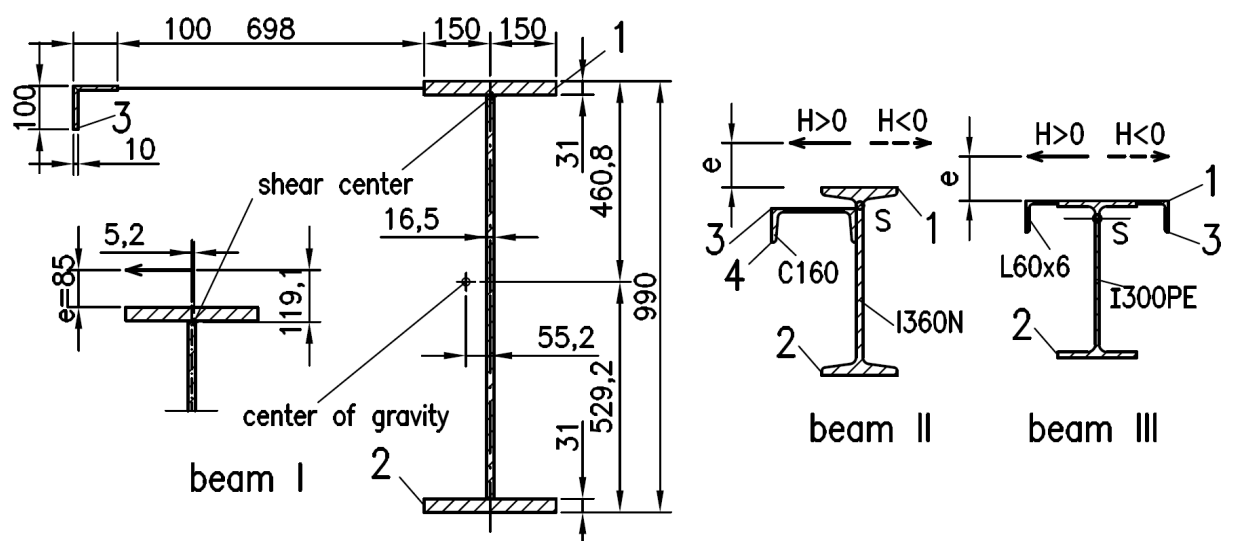

Fig. 2. Cross-sections of the analyzed beams (values of $e$ are shown in table 2)

Rys. 2. Przekrój poprzeczny analizowanych belek (wartości $e$ są pokazane w tabeli 2) 
In this article three existing overhead crane supporting beams were examined (Fig. 2): two with non-symmetrical cross-sections (beam I and beam II) and one with mono-symmetrical cross-section (beam III). The static schemes of these beams are presented on fig. 3 and the values of loads in Table 1 .

Table 1. Loads (obtained from accessible design data) and coordinates

Tabela 1. Obciążenia (otrzymane z dostępnych danych projektowych) i współrzędne

\begin{tabular}{|c|c|c|c|c|c|c|c|c|}
\hline \multirow{3}{*}{$\begin{array}{l}\text { Kind } \\
\text { of load }\end{array}$} & \multirow{3}{*}{$\begin{array}{l}\text { Case } \\
\text { of load }\end{array}$} & \multicolumn{4}{|c|}{ beam I } & \multirow{2}{*}{\multicolumn{2}{|c|}{$\frac{\text { beam II and III }}{\text { to Fig. } 3}$}} & \\
\hline & & \multicolumn{4}{|c|}{ point on the span according to Fig. 3} & & & \\
\hline & & P1 & $\mathrm{P} 2$ & $\mathrm{P} 3$ & $\mathrm{P} 4$ & P1 & $\mathrm{P} 2$ & \\
\hline Vertical $P_{i}$ & $\mathrm{~A}, \mathrm{~B}, \mathrm{C}, \mathrm{D}$ & 212 & 207 & 207 & 212 & 65,0 & 65,0 & $\mathrm{kN}$ \\
\hline \multirow{4}{*}{$\begin{array}{c}\text { Horizontal } \\
H_{i}\end{array}$} & A & 35,6 & 16,3 & 5,3 & $-14,0$ & 17,5 & - & $\mathrm{kN}$ \\
\hline & $\mathrm{B}$ & $-14,0$ & 5,3 & 16,3 & 35,6 & $-17,5$ & - & $\mathrm{kN}$ \\
\hline & $\mathrm{C}$ & 73,6 & 0,0 & 0,0 & $-73,6$ & - & - & $\mathrm{kN}$ \\
\hline & $\mathrm{D}$ & $-73,6$ & 0,0 & 0,0 & 73,6 & - & - & $\mathrm{kN}$ \\
\hline$a_{i}$ & $\mathrm{~A}, \mathrm{~B}, \mathrm{C}, \mathrm{D}$ & 1,85 & 4,00 & 5,23 & 7,38 & 1,93 & 4,22 & $\mathrm{~m}$ \\
\hline$b_{i}$ & $\mathrm{~A}, \mathrm{~B}, \mathrm{C}, \mathrm{D}$ & 10,15 & 8,00 & 6,77 & 4,62 & 3,07 & 0,78 & $\mathrm{~m}$ \\
\hline
\end{tabular}

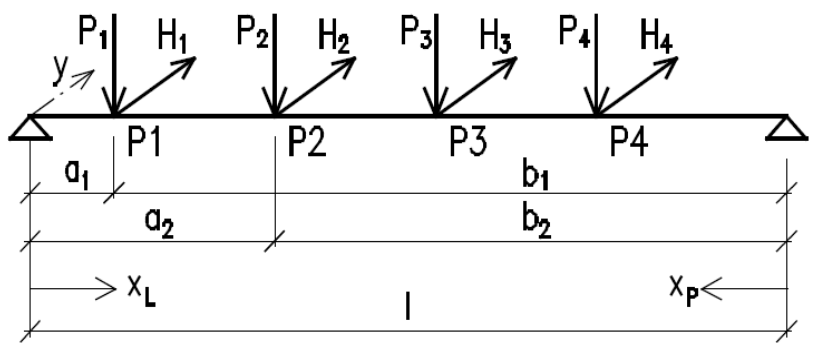

Length-span of the beams: Beam I: $l=12 \mathrm{~m}$, Beams II and III: $l=5,0 \mathrm{~m}$

Values of $a_{i}, b_{i}$ are given in Table 1.

Fig. 3. Static scheme of the analysed beams and coordinates.

Rys. 3. Schemat statyczny analizowanych belek i współrzędne

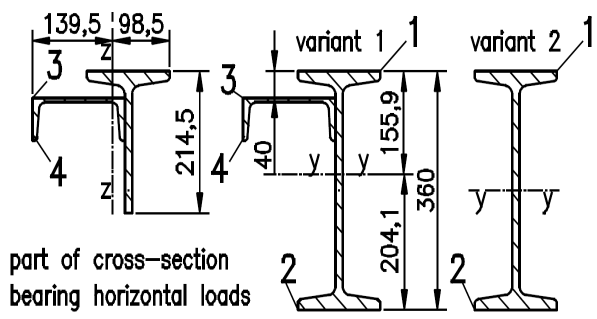

part of cross-section bearing vertical loads

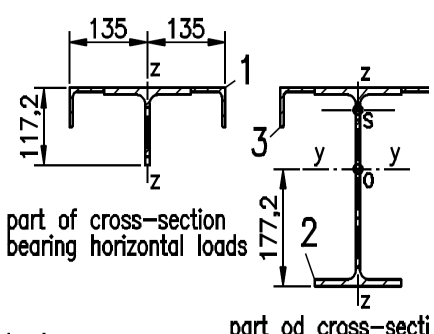

Dividing of cross-section of the beam I according to Fig. 1.

Fig. 4. Dividing of the cross-sections of beams II and III in simplified calculations Rys. 4. Podział przekroju poprzecznego belek II i III do obliczeń uproszczonych 
For the more accurate calculations, including warping torsion, the normal stresses (excluding the influence of lateral-torsional buckling) are the sum of the stresses resulting from bi-directional bending and bi-moments as follows:

$$
\sigma=\frac{M_{y} z_{i}}{I_{y}}+\frac{M_{z} y_{i}}{I_{z}}+\frac{B \omega_{i}}{I_{\omega}} .
$$

where: $M_{y}, M_{z}$ - bending moments in the major and minor axis,

$I_{y}, I_{z}-$ second moments of inertia in the major and minor axis,

$y_{i}, z_{i}$ - the distance from gravity center to the point $i$ of the cross-section,

$\omega_{i}-$ the sectorial area at a specified point of the cross-section,

$B$ - bi-moment, $I_{\omega}$ - warping constant of the cross-section.

The values of the bi-moments are calculated by formulas (2a) or (2b):

$$
\begin{aligned}
& B=\frac{M_{T i}}{k} \frac{\sinh \left(k\left(l-a_{i}\right)\right.}{\sinh (k l)} \sinh \left(k x_{L}\right), \\
& B=\frac{M_{T i}}{k} \frac{\sinh \left(k\left(l-b_{i}\right)\right.}{\sinh (k l)} \sinh \left(k x_{P}\right),
\end{aligned}
$$

in which: $k$ - flexural-bending characteristic, $l-$ span of the beam, $a_{i}, b_{i}-$ position of the torque load at the length of the beam, $x_{L}, x_{P}$ - position of the analysed cross-section (coordinates were shown on Fig. 3).

Formulas $2 \mathrm{a}$ or $2 \mathrm{~b}$ are used depending on the position of the crosssection, for which the value of the bi-moment was determined, relative to the place where torque loads have been applied to the beam.

Obtained values of the stress in selected points of the cross section of the beam according the fig. 2 are presented in the table 2. For the beam I differences of the stress values between two verified models reach a few percent. In case of the other beams with similar cross-sections the alike results were received. For the beams II and III the results between the stresses that ware obtained by the precise method and simplified method, were grater than for beam I. 
Table 2. Calculated maximum values of stresses for all cases of loads

Tabela 2. Obliczone wartości maksymalne naprężeń dla wszystkich przypadków obciążeń

\begin{tabular}{|c|c|c|c|c|c|c|c|}
\hline \multirow{3}{*}{ छ్ } & \multirow{3}{*}{$\begin{array}{c}\text { Point } \\
\text { acc. to } \\
\text { Figures } \\
2 \text { and } 4\end{array}$} & \multicolumn{3}{|c|}{$\begin{array}{c}\mathrm{e}=40 \mathrm{~mm}(\text { beam II and III }) \\
\mathrm{e}=85 \mathrm{~mm}(\text { beam I })\end{array}$} & \multicolumn{3}{|c|}{$\mathrm{e}=140 \mathrm{~mm}($ beam II and III $)$} \\
\hline & & Precise & Simplified & $\%$ & Precise & Simplified & $\%$ \\
\hline & & $\mathrm{MPa}$ & $\mathrm{MPa}$ & - & $\mathrm{MPa}$ & $\mathrm{MPa}$ & - \\
\hline \multirow{3}{*}{ - } & 1 & -210 & -188 & 10,7 & - & - & - \\
\hline & 2 & 179 & 161 & 9,9 & - & - & - \\
\hline & 3 & - & - & - & - & - & - \\
\hline \multirow{4}{*}{ 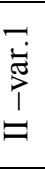 } & 1 & -167 & -146 & 12,3 & -176 & -146 & 16,8 \\
\hline & 2 & 129 & 87 & 32,4 & 112 & 87 & 22,0 \\
\hline & 3 & -119 & -162 & $-36,3$ & -124 & -162 & $-30,4$ \\
\hline & 4 & -106 & -134 & $-26,3$ & -129 & -134 & $-4,4$ \\
\hline \multirow{4}{*}{ 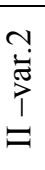 } & 1 & -167 & -168 & $-0,8$ & -176 & -168 & 4,4 \\
\hline & 2 & 129 & 88 & 31,5 & 112 & 88 & 21,0 \\
\hline & 3 & -119 & -112 & 5,4 & -124 & -112 & 9,5 \\
\hline & 4 & -106 & -112 & $-5,8$ & -129 & -112 & 12,5 \\
\hline \multirow{3}{*}{$\Xi$} & 1 & -240 & -237 & 1,2 & -263 & -237 & 9,9 \\
\hline & 2 & 184 & 165 & 10,2 & 291 & 165 & 43,3 \\
\hline & 3 & -215 & -181 & 15,7 & -280 & -181 & 35,3 \\
\hline
\end{tabular}

\subsection{Simplified method according to Eurocode}

According to Eurocode [5], the influence of the torque moment should be included in calculation of the runway beams for overhead cranes. In calculation model assumed in the Eurocode the influence of bi-moment resulting from warping torsion may be replaced by the influence of the additional loads $H_{M T}$ acting on the upper and lower flange of the beam and replacing torque moment $M_{T}$. The loads $H_{M T}$ can be calculated according to the formula (location of these loads has been shown in Fig. 5):

$$
H_{M T}=\frac{M_{T i}}{h},
$$

where: $h$-axial spacing of the I-beam flanges.

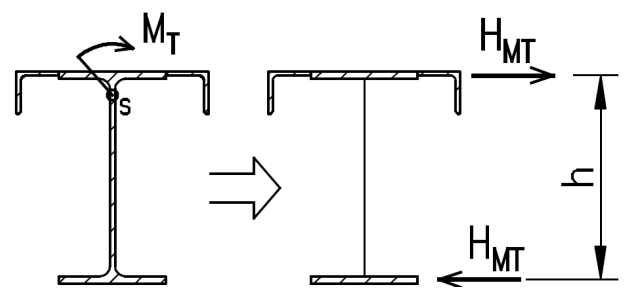

Fig. 5. Location of additional loads $H_{M T}$ replacing torque loads (EC Model)

Rys. 5. Położenie dodatkowych obciążeń $H_{M T}$ zastępujących obciążenie skręcające (EC Model) 
The calculation results for selected points of cross-section according to the standard simplified and precise calculation models including the influence of bi-moment have been presented in the table 3. As we can see, the stress values in the lower flange are even up to $144 \%$ (for $H<0$ ) greater in EC model than those in precise model (that include the bi-moment) in case of beam II with high rail and about $63 \%$ in case of beam III.

Table 3. Max. values of stress including bi-moments and bending moments of flanges from $H_{M T}$

Tabela 3. Maksymalna wartości naprężeń wywołanych bimomentem i momentem zginającym pas od siły $H_{M T}$

\begin{tabular}{|c|c|c|c|c|c|c|c|}
\hline \multirow{3}{*}{ Е్ } & \multirow{3}{*}{$\begin{array}{l}\text { Point } \\
\text { acc. to } \\
\text { Fig. } 2\end{array}$} & \multicolumn{3}{|c|}{$\mathrm{e}=40 \mathrm{~mm}$} & \multicolumn{3}{|c|}{$\mathrm{e}=140 \mathrm{~mm}$} \\
\hline & & $\begin{array}{c}\text { Precise } \\
\text { (Vlasov) }\end{array}$ & $\begin{array}{c}\text { Simplified } \\
\text { (EC) }\end{array}$ & $\%$ & $\begin{array}{c}\text { Precise } \\
\text { (Vlasov) }\end{array}$ & $\begin{array}{c}\text { Simplified } \\
\text { (EC) }\end{array}$ & $\%$ \\
\hline & & $\mathrm{MPa}$ & $\mathrm{MPa}$ & - & $\mathrm{MPa}$ & $\mathrm{MPa}$ & - \\
\hline \multirow{4}{*}{ 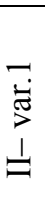 } & 1 & -167 & -163 & 1,8 & -176 & -187 & $-6,4$ \\
\hline & 2 & 129 & 166 & $-28,3$ & 112 & 271 & -142 \\
\hline & 3 & -119 & -187 & $-57,0$ & -124 & -220 & $-76,8$ \\
\hline & 4 & -106 & -159 & $-49,5$ & -129 & -192 & $-49,4$ \\
\hline \multirow{3}{*}{$\Xi$} & 1 & -240 & -269 & $-11,9$ & -263 & -311 & $-18,1$ \\
\hline & 2 & 184 & 296 & $-61,2$ & 291 & 474 & $-62,9$ \\
\hline & 3 & -215 & -213 & 1,1 & -280 & -255 & 9,0 \\
\hline
\end{tabular}

\section{Fatigue}

\subsection{Introductory remarks}

As the result of the introducing the new design rules [3], [4], [5] the size of the beam cross-sections has increased in comparison to the beams that were designed according to the previous rules. Such a situation results from the necessity of the reduction of the stresses in the cross-section due to the changes of the fatigue categories and higher values of the safety factors. The latter issue that has an influence on the situation is the obligation to take the local bending of the web into consideration during the assessment of fatigue resistance. A lot of doubts has arisen among the structural engineers because of the changes between [1] and [4], especially it considers the considerable changes of the fatigue categories for the elements with holes and the limitation of the possibility to reduce the compressive stresses range by $40 \%$.

\subsection{Fatigue capacity of elements with holes - Standard rules}

For joining the rail to the runway beam the rail clamps (clips) and bolts are often used and sometimes the secondary elements are also connected 
to the runway beams by bolts. So far the Polish Standard [1] has contained a few regulations that consider the fatigue load-bearing beam with holes capacity. More detailed rules has been introduced in standard [4] and [6].

There are three base types of the elements with holes (fig. 6): In type I the hole is not filled with fastener or the loads beared by the fastener do not change significantly the values of the internal forces in the element. That is the typical situation for the connection between the runway rail and the runway beam by the bolts and rail clamps and for the connection of the secondary elements with the beam. Type II considers elements connected with non-preloaded bolts or rivets, and the force that is transferred through fastener significantly alters the distribution of internal forces in the element. For example: lap or butt joints in splice connections of beams or columns. Type III contains whole range of connections that use preloaded bolts.
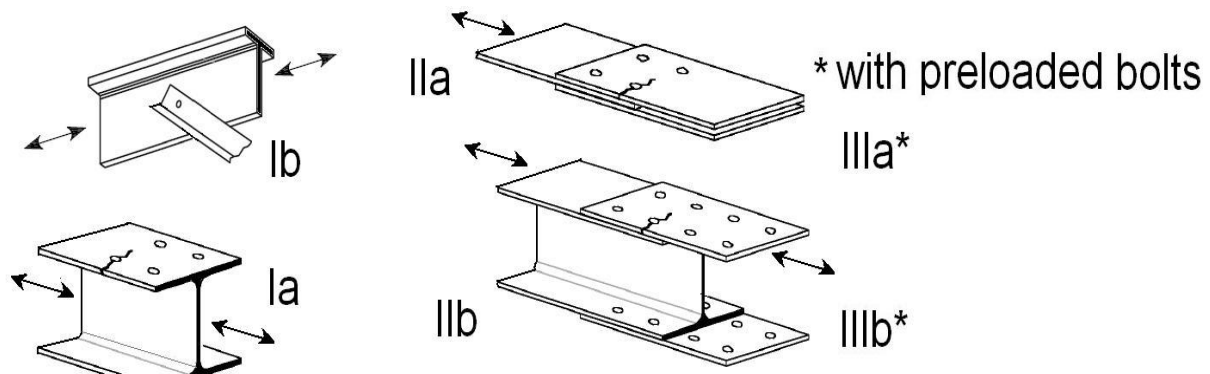

Fig. 6. Types of structural details with holes (see table 4)

Rys. 6. Typy szczegółów konstrukcyjnych z otworami (patrz tabl. 4)

In polish norm from 1990 [1] the only one fatigue category with high value of $140 \mathrm{MPa}$ (slightly smaller than for the base material $-160 \mathrm{MPa}$ ) has been introduced. Interestingly in the standard that has been issued in 1980 [2] the bearing fatigue capacity for the riveted and bolted connections with fitted bolts or high-strength bolts was varied. Moreover in [2] the fatigue strength depended on the type of steel and shows the values for carbon and low-alloy steels. In the standards [4] and [6] there is no influence between the steel type and the fatigue category, however such an influence was not only mentioned in the [2] standard but was also shown in the results of the examination. The values of the fatigue strength for $2 * 10^{\wedge} 6$ cycles for selected constructional details according to [1], [2], [4] and [6] are compared in the table 4 . The fatigue curves for chosen construction details with holes, assuming that value of the partial factor of the safety is 1 , are shown on the figures 7 . Some diversity of the values is noticeable. 
Table 4. The values of the fatigue strength for $\mathrm{N}=2 * 10^{6}$ cycles

Tabela 4. Wartości nośności zmęczeniowej przy $\mathrm{N}=2 * 10^{6}$ cykli

\begin{tabular}{|c|c|c|c|c|c|}
\hline \multirow{3}{*}{$\begin{array}{l}\text { Description of detail (type) ac- } \\
\text { cording to Fig. } 6 \text { : }\end{array}$} & \multicolumn{5}{|c|}{ Fatigue strength at $2 * 10^{6}$ cycles acc. to: } \\
\hline & \multicolumn{2}{|c|}{$\begin{array}{c}\mathrm{PN}-80 \\
\mathrm{~B}-03200\end{array}$} & $\begin{array}{c}\text { PN-90 } \\
\text { B-03200 }\end{array}$ & $\begin{array}{c}\text { EN } \\
1993-1-9\end{array}$ & AISC \\
\hline & \multicolumn{5}{|c|}{$\begin{array}{c}\left.\mathrm{MPa}^{2}\right) \\
\text { (stress category according to Fig. 7) }\end{array}$} \\
\hline $\begin{array}{c}\text { Element with drilled } \\
\text { or reamed empty holes (Ia) }\end{array}$ & 116 & 125 & $\begin{array}{c}140 \\
(140)\end{array}$ & $\begin{array}{c}90 \\
(90)\end{array}$ & $\begin{array}{l}124 \\
(\mathrm{~B})\end{array}$ \\
\hline $\begin{array}{l}\text { Element like above, containing } \\
\text { bolts for attachment of light } \\
\text { bracings with small longitudinal } \\
\text { component of brace force }(\mathrm{Ib})\end{array}$ & $116^{3)}$ & $125^{3)}$ & $\begin{array}{c}140 \\
(140)\end{array}$ & $\begin{array}{c}90 \\
(90)^{3)}\end{array}$ & $\begin{array}{l}89 \\
(\mathrm{C})\end{array}$ \\
\hline $\begin{array}{c}\text { Element with weld access empty } \\
\text { holes (Ia) }\end{array}$ & - & - & - & - & $\begin{array}{l}89 \\
(\mathrm{C})\end{array}$ \\
\hline $\begin{array}{l}\text { Double covered joint with } \\
\text { preloaded bolts (IIIa) }\end{array}$ & 139 & 148 & $\begin{array}{c}140 \\
(140)\end{array}$ & $\begin{array}{c}112 \\
(112)\end{array}$ & $\begin{array}{l}124 \\
(\mathrm{~B})\end{array}$ \\
\hline $\begin{array}{l}\text { One sided connection with pre- } \\
\text { loaded bolts (IIIb) }\end{array}$ & - & - & $\begin{array}{c}140 \\
(140)\end{array}$ & $\begin{array}{c}90 \\
(90)\end{array}$ & - \\
\hline $\begin{array}{l}\text { Joint with snug bolts in normal } \\
\text { clearance holes (IIa) }\end{array}$ & 4) & 4) & - & $\begin{array}{c}50 \\
(50)^{5)}\end{array}$ & $\overline{4}$ \\
\hline $\begin{array}{l}\text { Other mechanically fastened } \\
\text { joint eg. lap riveted joint }\end{array}$ & 78 & 85 & $\begin{array}{c}140 \\
(140)\end{array}$ & - & $\begin{array}{l}71 \\
\text { (D) }\end{array}$ \\
\hline $\mathrm{k}^{1)}$ & 0 & 0,1 & - & - & - \\
\hline \multicolumn{6}{|c|}{$\begin{array}{l}\text { T) } k \text {-ratio between the lower and upper tension (see also point } 2.5 \text { ) } \\
\text { 2) values obtained for the safe factor value equal } 1,0 \\
\text { 3) approx. assumption - not enough precise description of detail in Standard } \\
\text { 4) connection subjected to fatigue should be designed as slip-critical } \\
\text { 5) no load reversal }\end{array}$} \\
\hline
\end{tabular}

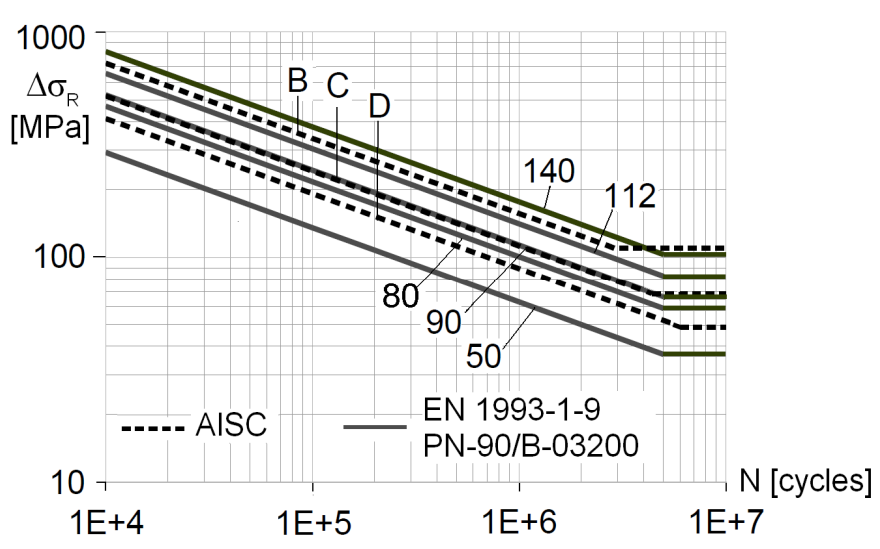

Fig. 7. The comparison between the fatigue strength curves according to different standards

Rys. 7. Porównanie nośności zmęczeniowej z krzywymi z krzywymi wg. różnych przepisów 
According to the American Standard [6] the expected number of cycles leading to destruction under determined stress level has considered only the elements with the drilled or sub-punched and reamed holes. In the Eurocode [4] such an information was not given in extenso in the description of the construction details category. According the EN 1090-2 there is a possibility to perform the construction in EXC2 class assuming the low consequence class $\mathrm{CC} 1$ according to EN 1990-2. One must emphasize that in the EXC2 class there are no requirements to ream the holes and thus the real fatigue category can be slightly lower. Moreover if the class of the construction is not provided, the construction is performed in the EXC2 class. Thus the whole elements exposed to the fatigue should be designed as the EXC3 class.

\subsection{The researches on the fatigue life of the plate elements with holes}

Taking into account the possibility of accelerating the production process by punching the holes, for the elements that are exposed to fatigue, the researches focusing on the fatigue life of the aforementioned elements has been conducted [7], [10], [13], [16]. The results of the research for the elements with punched holes have indicated that their fatigue strength is located between the curves D and B (compare Fig. 7), which more or less corresponds to the 80 and 112 categories, exceptionally the fatigue strength is slightly below the curve D. For the elements with drilled holes the results were always over the curve $\mathrm{C}$ and frequently even little over the curve B, however the examination based on number of cycles greater than $1 * 10^{\wedge} 6$ revealed that the bearing capacities of the elements has been always over the curve B. The influence of the preloaded bolt used in plate with holes (bolt is not the connector) gaining the slight increase of the fatigue strength is mentioned in [8]. However one should note that the number of cycles to failure (fatigue life) of the element with holes drilled by worn drill bit may be nearly the same as in the element with punched holes [10]. Thus it is very important to provide the right quality to the hole surface. The Standard EN 1090-2 provides the reference to the ISO standard that concerns the issues of the surface quality after cutting and polishing. Notwithstanding the authors of [13] indicates that the result discrepancies between fatigue life of the elements with drilled and punched elements might not fit to the matter of fact due to the high quality of the laboratory obtained drilled holes. However the less deformability and slightly less bearing-capacity is obtained for the elements with punched holes even under the static loads. In the papers [16] and [17] the extensive studies for the galvanized and not galvanized samples with punched and drilled holes has been described. The fatigue strength values of the galvanized samples were over the curve provided for the category 71 , and for not-galvanized samples over the curve for the category 90 . 


\subsection{The researches on the fatigue life of the lap joints and butt joints}

A significant amount of results gathered in [13] revealed that the bearing capacity of the butt joints with 2, 4 and 6 snug bolts or pre-loaded bolts on one side of them mostly were over the curve B. The curve B within about $4,5^{*} 10^{\wedge} 6$ cycle numbers is between 112 and 140 category according to [4] and [1]. Beyond that range the curve $\mathrm{B}$ correspond to the slightly higher curve than was established for 140 category (compare Fig. 6). Similar result concerning the pretensioned connections has been presented in [10]. Nevertheless in case of the single bolted or double bolted butt joints with 2 or 4 non-preloaded bolts, the fatigue stress capacity of the connection with punched and drilled holes resembled the curve B (revealing some fluctuation of the values). The authors [10], [13] have classified such a connection to the D category that corresponds to the 71 category according to [4]. The bearing capacities for one bolt connection with two splices for the not-galvanized elements with drilled holes presented in [17] correspond to the curve for 71 category, and for the galvanized elements with the punched holes slightly above the curve 36 . The adverse influence of the galvanization process was reduced due to the use of high-strength bolts in the connection. Generally most of the authors suggest that the influence of the reaming or galvanization is utterly insignificant in the pre-tensioned connection. The separate issue is use of the resin injected bolts. Less bearing capacity has been obtained for the elements that contain the bolts with injection than for elements with standard bolt at the same rate of the tightening moment.

\subsection{The influence of the reversal loading and compressive stresses}

The researches that were presented in many papers mostly were conducted under the tensile fluctuating load with the constant amplitude and for ratio between the lower and upper tension in the net section equal about 0,1 e.g. [10], [17]. Sometimes it was from 0,1 up to 0,4 with constant ratio between minimum stress and yield stress equal 0,1. Non-reversal fluctuating load is typical for runway beams and in that context the results interpretation can be useful for the assessment of the stress category. However, the full stress range has not been included in that researches. Furthermore, there is a significant difference in a durability of the compressed and tensioned sample under the same absolute value of the maximum stress, that was included in Polish Standards [1], [2]. The included recommendations fit to the many results that were quoted in [13] and [15], where it was concluded that the reduction of the compressive stress range by $40 \%$ under the reversal load for the bolted and riveted connections should be taken into consideration. 


\subsection{The slope of the fatigue curves for bolted joints}

The whole results for the bolted connections indicated that the slope of fatigue curves is smaller than presented in Eurocodes [4] and American standards [6]. Suggested changes concerning the fatigue curves have been presented in [17].

\subsection{Fatigue life of the old connections}

A lot of attention has been paid to the bear capacity of the old riveted structures. Also the runway beams from the $30 \mathrm{~s}$ of the twentieth century are still used. In the paper [15] the category $\mathrm{C}$ for the new drilled elements has been introduced apart from the age of the steel and the category D for the assessment of the connection with the old holes has been introduced. Such a conclusion does not concern the wrought steel. In the [12] the fatigue category 71 is recommended, independently of the hole performing. Those recommendations correspond with the results of the researches shown in [9]. In some cases category 63 is possible [14]. The shape of the fatigue curve for the riveted connections otherwise than for the bolted connections correspond to that proposed in [4] and [6]. According to the conclusions that are shown in [14], the influence of the holes performing is not enough to differentiate the fatigue categories. More advanced method of assessment the old structures durability are described in [12].

\section{Conclusions}

\subsection{Normal stresses calculation}

Three models of overhead cranes runway beams has been discussed in that paper. In the simplified model the upper flange fiber stresses are obtained from the sum of both vertically loaded beam and horizontally loaded brace. In the more precise model the influence of the bi-directional bending and the Saint-Venant and warping torsion is included. In the European standards the influence of the bi-moment may be replaced by the influence of the horizontal bending of the beam flanges loaded additionally with the substitute loading forces $H_{M T}$. The use of the simplified method of calculating the beams with the broad horizontal braces (as shown in Fig. 1a) according to [1] can be considered appropriate under condition of $10 \%$ stock of the beam load capacity. The assumed reserve of load capacity is derived from a few percentage lowering of the stress values in the critical cross-section which is a result of use of the simplified model (Fig.1). That difference can by reduce by including additional loads $H_{M T}$ acting to the flanges as is assumed in Eurocode [4]. The application of aforementioned method for beams with a smaller brace as shown in Fig. 1b may be not appropriate, however it was permitted 
in Polish Standard [1]. The force $H_{M T}$ acting on the lower flange of the simply supported beam caused overestimation of the normal stress values in the lower flange about $\%$ in comparison to the calculation model with bi-moment. The simplified method of including the bi-moment assumed in Eurocode (as seen on Fig. 5) is accurate for the shell beam models.

Taking into account the market necessity of utilization the maximal load capacity of the beams, using the more precise calculation models including the warping torsion may be reasonable, what is accessible and comfortable nowadays because of computer programs. The geometrical characteristics of the cross-section or the shell models can be modeled in a very quick way. However there are no widely available computer programs which enable to model the bidirectional bended rod with Saint-Venant and warping torsion to determine in a simple way the influence of bi-moment to the state of utilization of load capacity of the overhead crane runway beams.

\subsection{Fatigue}

The changes introduced in Eurocode concerning the fatigue calculation seem to be the most important to construct the shape of the beams. Among the whole doubts reported by structural engineers, the issues of the fatigue category qualification for the beam with holes has been presented in this paper.

Based on the accessible results it can be concluded that the fatigue categories assumed in the Eurocode for the tensioned elements with holes are not too rigorous. It seems that the additional modification of existing fatigue curves for details that has been shown in that paper would be advisable. Such an approach may allow to precise the assessment of fatigue load capacity. Moreover, it should be defined in Eurocode for which type of the holes (punched or drilled) the fatigue category was determined. Alternatively the necessity to include the execution class EXC3 in the beam design documentation should be mentioned. Lack of data in the Standards that would allow for a more accurate assessment of the elements fatigue life for the repeatable compressive stresses is still an issue. Such information would allow for both safe and more economical design of the beams.

\section{Bibliography}

[1] PN-90/B-03200: Polska Norma. Konstrukcje stalowe. Obliczenia statyczne i projektowanie (Polish Standard. Steel Structures. Design Rules)

[2] PN-80/B-03200: Konstrukcje stalowe. Obliczenia statyczne i projektowanie (Polish Standard. Steel structures. Design rules)

[3] EN 1991-3: Eurocode 1: Action on structures - Part 3: Actions induced by cranes and machinery

[4] EN 1993-1-9: Eurocode 3: Design of steel structures - Part 1-9: Fatigue. 
[5] EN 1993-6: Eurocode 3: Design of steel structures - Part 6: Crane supporting structures.

[6] ANSI/AISC 360-05: Specification for Structural Steel Buildings. AISC, 2007.

[7] Alegre, J.M., Aragon A., Gutierrez-Solana F.: A finite element simulation methodology of the fatigue behavior of punched and drilled plate components. Engineering Failure Analysis Vol. 11. pp 737-750.2004.

[8] Aragon A., Alegre, J.M., Gutierrez-Solana F.: Effect of clamping force on the fatigue behaviour of punched plates subjected to axial loading. Engineering Failure Analysis Vol. 13. pp. 737-750., 2006.

[9] Di Battista, J. D., Adamson, D. E. J., Kulak G. L.: Fatigue Strength of Riveted Connections. Journal of Structural Engineering, 124 (7), 792-797.

[10] Brown J.D., Lubitz D.J., Cekov Y.C., Frank K.H., Keating P.B.: Evaluation of Influence of Hole Making Upon the Performance of Structural Steel Plates and Conn.. CTR Technical Report:0-4624-1, 2007 (www.utexas.edu/research/ctr)

[11] MacCrimmon R.A.: Guide for the design of crane-supporting steel structures. Second edition. Canadian Institute of Steel Construction. Ontario 2009.

[12] Kühn B. et al.: Assessment of existing steel structures: recommendations for estimation of remaining fatigue life. JRC Scientific and Technical Report no. 43401. European Commission, Joint Research Centre, Luxembourg 2008.

[13] Kulak G.L., Fisher, J.W., Struik J.H.A.: Guide to design criteria for bolted and riveted joints. $2^{\text {nd }}$ edition, RCSC 1987.

[14] Larrson T.: Fatigue assessment of riveted bridges. PhD Thesis, Lulea University of Technology, February 2009.

[15] Out J.M. M., Fisher J.W., Yen B.T.: Fatigue strength of weathered and Deteriorated riveted members. Fritz Eng. Laboratory Report 483 3(84), Lehigh University 1984

[16] Valtinat G., Huhn H.: Bolted connections with hot dip galvanized steel members with punched holes. Proceedings of the ECCS/AISC Workshop: Connections in Steel Structures V. Amsterdam, June 3-4, 2004, pp. 297-310.

[17] Valtinat G., Huhn H.: Scher-Lochleibungs-Verbindungen mit feuerverzinkten Stahlbauteilen und gestanzten Löchern unter Betriebsbeanspruchungen

\section{WYBRANE ASPEKTY OBLICZANIA BELEK PODSUWNICOWYCH}

\section{Streszczenie}

Przez ostatnie kilka lat normy europejskie (EN) dotyczące projektowania belek podsuwnicowych były przedstawiane przez wiele krajów. Ogólne podejście projektowe i wytyczne szczegółowe przedstawione w tych dokumentach różnią się częściowo od poprzednio obowiązujących krajowych zasad projektowych. Obliczenia prowadzone na podstawie nowych norm, przeważnie wskazują na większe wykorzystanie nośności, dotyczy to szczególnie nośności zmęczeniowej. Prowadzi to do projektowania zwiększonych przekrojów belek. Z drugiej strony inwestorzy wymagają ekstremalnej redukcji ciężaru konstrukcji. Jest to duże wyzwanie dla inżynierów budowlanych, którzy projektują konstrukcję bez jakiegokolwiek zapasu nośności. W takim kontekście, artykule przedstawiono legalność uproszczonej metody obliczeń, która była używana do tej pory. W tym celu wykonano przykładowe obliczenia nośności belek o różnych przekrojach, według metody dokładnej i uproszczonej. Wnioski dotyczące różnicy wyników wskazują na możliwość 
zaakceptowania wartości naprężeń z modelu uproszczonego. W artykule przedstawiono również problemy związane oszacowaniem nośności zmęczeniowej. Skupiono się głównie na nośności elementów osłabionych otworami. W powyższym kontekście, z wynikami badań porównano normy amerykańskie, europejskie, oraz inne dostępne wytyczne.

Słowa kluczowe: nośność zmęczeniowa, szczegóły konstrukcyjne z otworami, metoda uproszczona, naprężenia

Przestano do redakcji:26.05.2015

Przyjęto do druku:1.12.2015

DOI: $10.7862 / \mathrm{rb} .2015 .145$ 